\title{
Syntheses of porphyrins isolated from the Coral Sea demosponge Corallistes sp.
}

\author{
Ravindra K. Pandey, ${ }^{a, b}$ Sam H. Leung, ${ }^{a}$ and Kevin M. Smith** \\ ${ }^{a}$ Department of Chemistry, University of California, Davis, CA 95616, USA, \\ ${ }^{b}$ Chemistry Section, Photodynamic Therapy Center, Department of Radiation Biology, Roswell \\ Park Cancer Institute, Buffalo, NY 14263, USA, and \\ ${ }^{c}$ Department of Chemistry, Louisiana State University, Baton Rouge, LA 70803, USA \\ E-mail: kmsmith@lsu.edu
}

\begin{abstract}
Dedicated to Professor Charles W. Rees on the occasion of his $75^{\text {th }}$ birthday
(received 24 May 02; accepted 18 Oct 02; published on the web 26 Oct 02)
\end{abstract}

\begin{abstract}
Methyl esters 2, 3, and 5 of corallistins B, C, and E, respectively, isolated from the Coral Sea demosponge Corallistes sp., were successfully synthesized by the MacDonald method (for corallistin $\mathrm{B}$ ester) and via a,c-biladiene cyclization (for corallistins $\mathrm{C}$ and $\mathrm{E}$ esters). In order to compare with the ${ }^{1} \mathrm{H}-\mathrm{NMR}$ data reported in the literature, zinc(II) complexes of these corallistins were prepared, and their ${ }^{1} \mathrm{H}-\mathrm{NMR}$ spectra were measured. Most chemical shifts were found to be within $0.1 \mathrm{ppm}$ of the reported values, except in the case of corallistin B ester, where signal broadening due to porphyrin aggregation made the comparison with literature values difficult. Overall, the NMR data provided support for the structures proposed for the natural corallistins. Postulates on the biosynthetic origins of the corralistins are also presented.
\end{abstract}

Keywords: $a, c$-Biladiene, Corallistes, natural product, NMR spectra, porphyrin, sponge, synthesis

\section{Introduction}

In 1989, Pietra and coworkers ${ }^{1}$ isolated a novel metal-free porphyrin (as its dimethyl ester) from the Coral Sea demosponge Corallistes sp., and named it corallistin A dimethyl ester (1). This became the second metal-free porphyrin isolated from a living organism (chlorophyll-c being the first). Corallistin A (the dicarboxylic acid) is present in huge amounts in the sponge, but the role of this porphyrin is still unknown. This stimulated Pietra and co-workers to further examine the demosponge, and eventually five more metal-free porphyrins were isolated. ${ }^{2}$ These included four new corallistins (as their methyl esters) - B (2), C (3), D (4), and E (5) - and the long-known deuteroporphyrin-IX dimethyl ester (6). Among the corallistins isolated so far, corallistin A was 
synthesized by Yon-Hin and Scott ${ }^{3}$ soon after its isolation, and corallistin D dimethyl ester $(\mathbf{4}=$ 3-ethyldeuteroporphryin-IX dimethyl ester), is already known in the literature. ${ }^{4,5}$ Compound 4 had been synthesized to confirm the structure of the heme isolated from cytochrome c558 ${ }^{4}$ and for NMR studies of heme proteins. ${ }^{5}$ In order to complete the synthesis of the whole corallistin series and for structural confirmation, we now report the syntheses of the three remaining corallistins - corallistin B, corallistin $\mathrm{C}$, and corallistin $\mathrm{E}$, as their corresponding methyl esters $\mathbf{2}$, 3 , and 5 , respectively. ${ }^{6}$

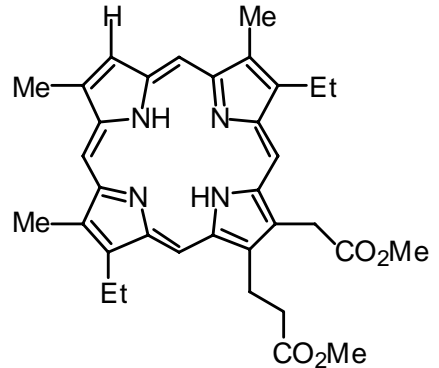

1: Corallistin A dimethyl ester

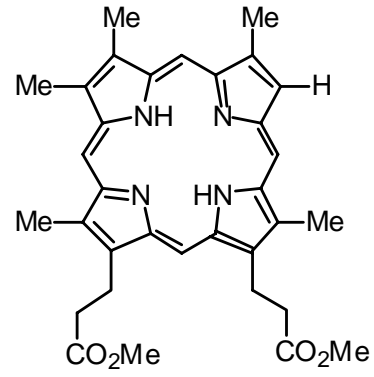

4: Corallistin D dimethyl ester

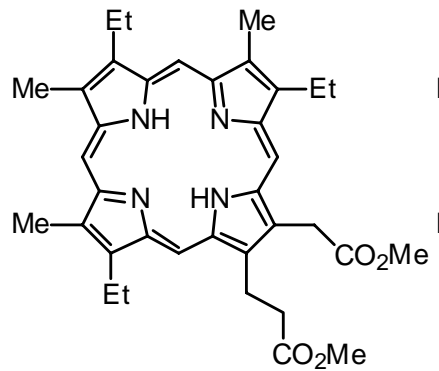

2: Corallistin B dimethyl ester

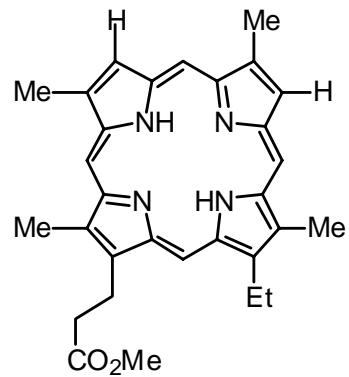

5: Corallistin E methyl ester

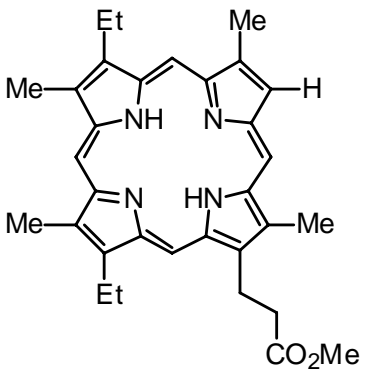

3: Corallistin $\mathrm{C}$ methyl ester

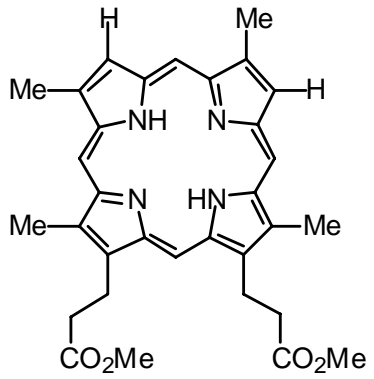

6: Deuteroporphyrin-IX dimethyl ester

\section{Results and Discussion}

\section{Synthesis of Corallistin B dimethyl ester (2)}

In principle, corallistin B dimethyl ester (2) can be synthesized by two different routes: the $a, c-$ biladiene route or the MacDonald route. ${ }^{7,8}$ After consideration of symmetry issues and monopyrrole availability, we decided that the MacDonald route was the more straightforward approach. Scheme 1 shows the synthetic route which was used. Because of the symmetry in one of the required dipyrromethanes, only three different pyrroles were needed to accomplish this total synthesis.

The known 2-unsubstituted pyrrole 7 and acetoxymethylpyrrole 8 were condensed, in the presence of Montmorillonite K10 clay, to give dipyrromethane $\mathbf{9}$ which was catalytically debenzylated to give the dipyrromethane dicarboxylic acid 10. Using a variation of the MacDonald [2+2] cyclization procedure, 1,9-diformyldipyrromethane $\mathbf{1 1}$ and dipyrromethane1,9-dicarboxylic acid $\mathbf{1 0}$ were condensed in the presence of $p$-toluenesulfonic acid. Air oxidation 
of the intermediate porphodimethene was facilitated by the addition of zinc(II) acetate with concomitant zinc insertion. Demetalation with TFA gave the desired corallistin B dimethyl ester (2) (Scheme 1).

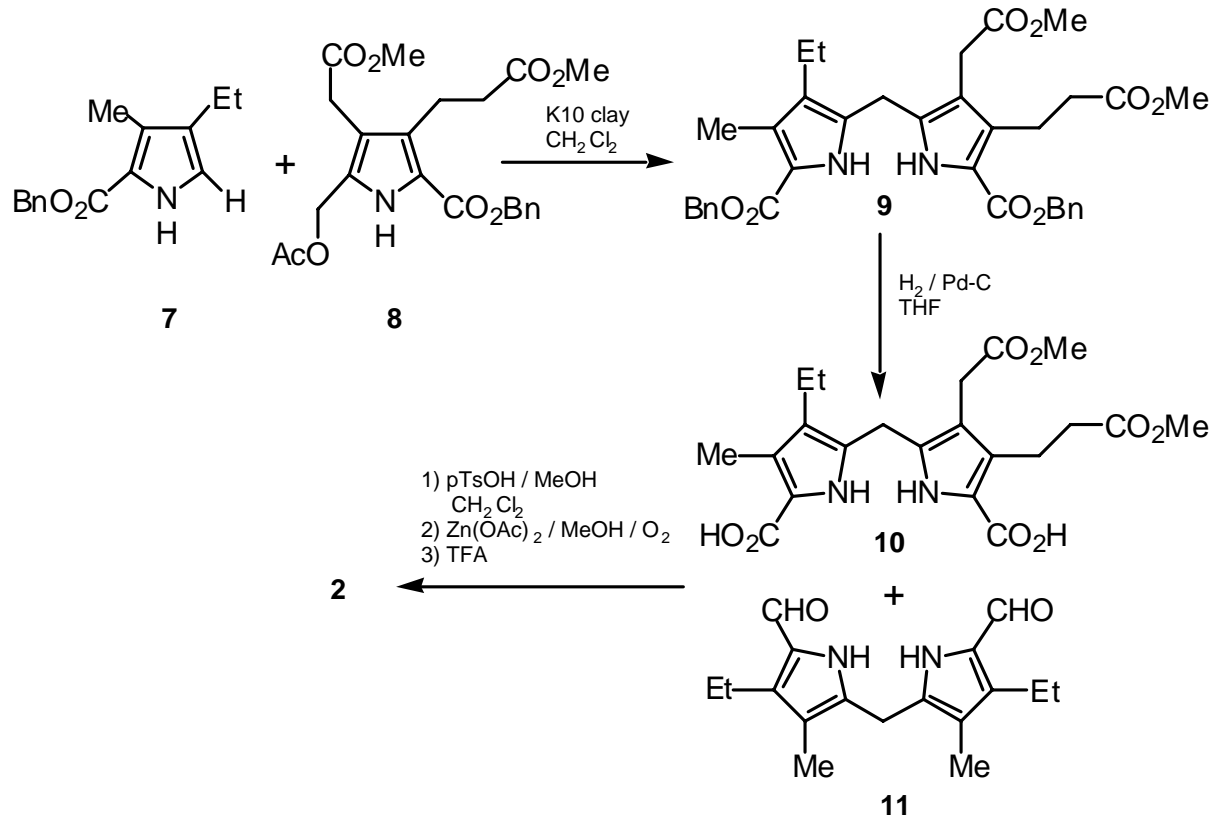

Scheme 1. Synthesis of corallistin B dimethyl ester (2).

\section{Synthesis of Corallistin C methyl ester (3)}

When one considers substituent symmetry aspects, Corallistin C methyl ester (3) can also, in principle, be synthesized by the MacDonald route. ${ }^{7,8}$ However, based on a retrosynthetic analysis of the ease of preparation of the required pyrroles, we chose instead to use a,c-biladiene cyclization $^{9}$ as the synthetic route for corallistin $\mathrm{C}$ methyl ester (3). Four different, but readily available, pyrroles were required for the synthesis (Scheme 2).

Condensation of known pyrroles 12 and 13 in the presence of Montmorillonite K10 clay gave dipyrromethane 14. This was catalytically debenzylated to afford dipyrromethane-1,9carboxylic acid 15 before being reacted with formylpyrrole 16 in the presence of $p$ toluenesulfonic acid; the tripyrrin $\mathbf{1 7}$ was isolated as its hydrobromide salt (Scheme 2). After the removal of the tert-butyl ester group on tripyrrin 17 with TFA, and reaction with formylpyrrole 18, the a,c-biladiene was isolated as its dihydrobromide salt 19, and was macrocyclized in DMF in the presence of copper(II) acetate to form the copper(II) porphyrin 20. Corallistin C methyl ester (3) was obtained after the removal of copper from porphyrin 20 using $15 \% \mathrm{H}_{2} \mathrm{SO}_{4} / \mathrm{TFA}$. 


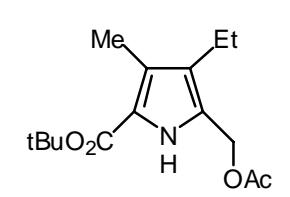

12

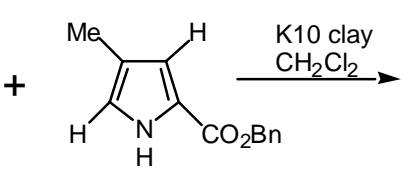

13

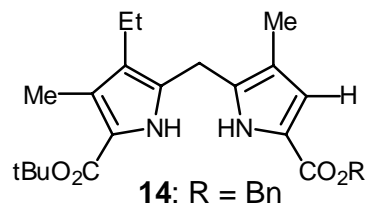

$$
\begin{gathered}
\downarrow \\
\text { 15: } \mathrm{R}=\mathrm{H}
\end{gathered}
$$

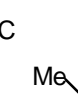

$\mathrm{Me}$

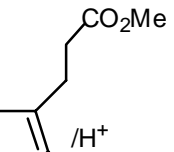

3
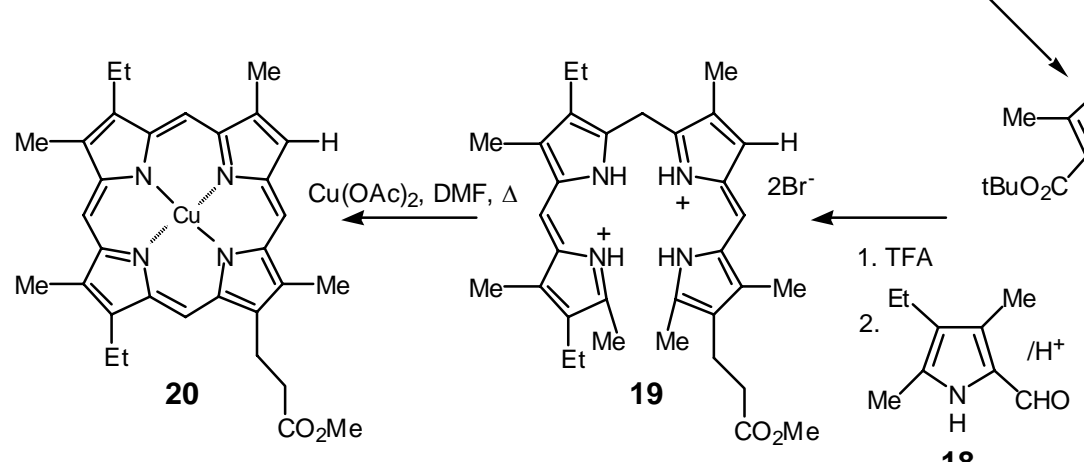

17

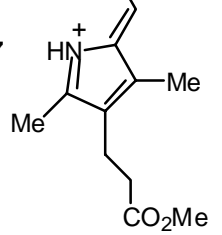

18

Scheme 2. Synthesis of corallistin C methyl ester (3).

\section{Synthesis of Corallistin E methyl ester (5)}

The substituent pattern in corallistin E methyl ester (5) is totally unsymmetrical, so this porphyrin is best synthesized by the a,c-biladiene route. ${ }^{9}$ A simple inspection leads to the fact that the structure of corallistin E methyl ester (5) is very similar to that of deuteroporphyrin-IX dimethyl ester (6). It has been known that deuteroporphyrin-IX dimethyl ester (6) can be obtained from hemin (21) by double protio-devinylation followed by the removal of iron. In planning the synthesis for corallistin E methyl ester (5), we decided to take the same approach to fashion the vacant positions at the 3- and 8-positions, as in the deuteroporphyrin-IX dimethyl ester (6) synthesis. Therefore the key intermediate would be a divinylporphyrin 22, which, being totally unsymmetrical, would be synthesized through the a,c-biladiene route.

The known bis(2-chloroethyl)dipyrromethane 23 (Scheme 3) was treated with TFA to remove the tert-butoxycarbonyl group, and the reacted with formylpyrrole $\mathbf{1 8}$ to form tripyrrin hydrobromide salt $\mathbf{2 4}$. To cleave the benzyl ester, tripyrrin hydrobromide salt $\mathbf{2 4}$ was stirred at room temperature in $\mathrm{TFA} / 30 \% \mathrm{HBr} /$ acetic acid, and the product was then reacted with formylpyrrole $\mathbf{1 6}$ to form the required $a, c$-biladiene, which was isolated as its dihydrobromide salt 25. $a, c$-Biladiene 25 was then cyclized with copper(II) acetate/DMF, and removal of copper gave bis(2-chloroethyl)porphyrin 26. 


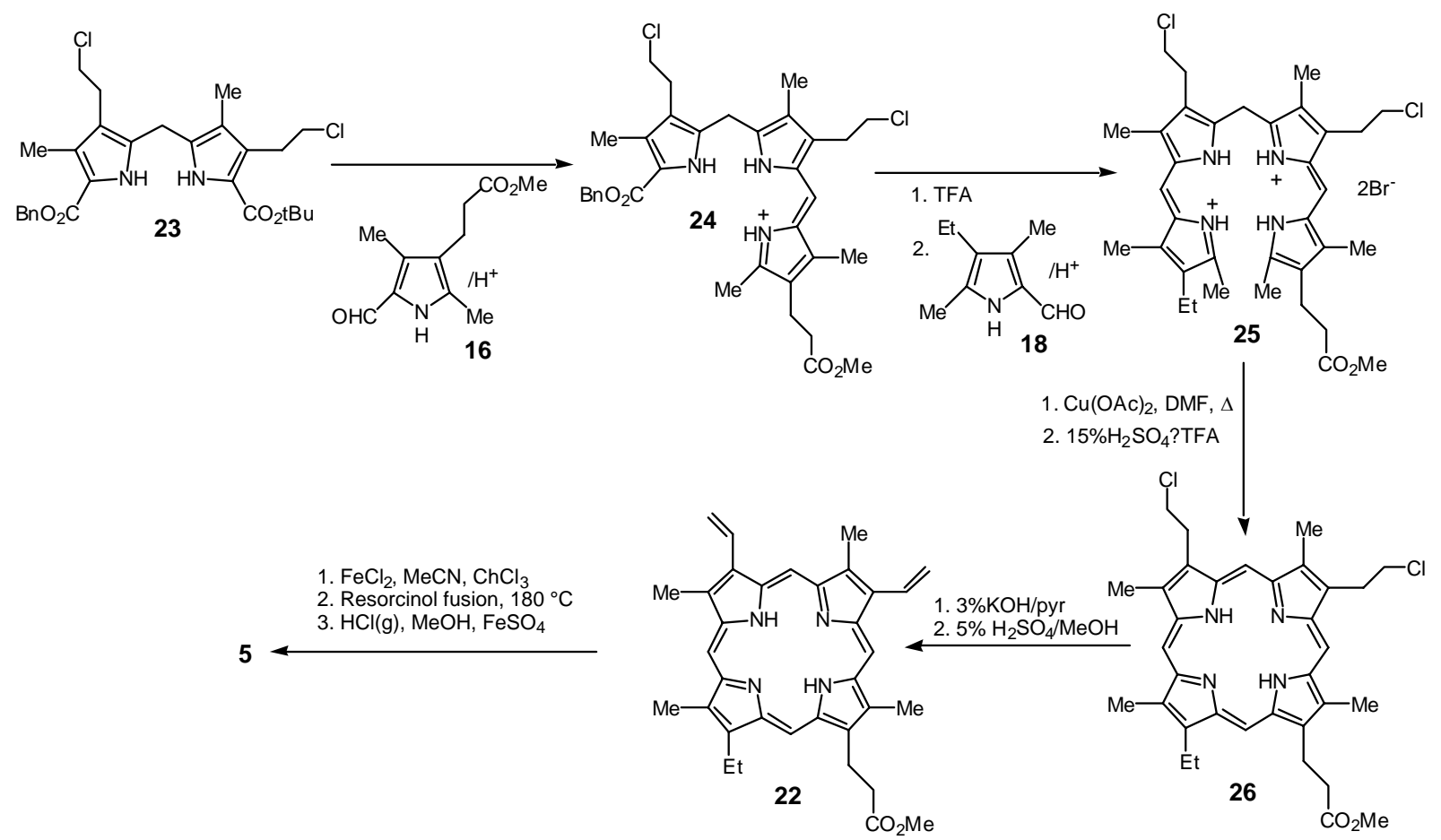

Scheme 3. Synthesis of corallistin E methyl ester (5).

Double dehydrohalogenation with 3\% aqueous potassium hydroxide/pyridine and subsequent esterification with $5 \% \mathrm{H}_{2} \mathrm{SO}_{4} / \mathrm{MeOH}$ afforded the divinylporphyrin methyl ester 22. To obtain the desired corallistin E methyl ester (5), porphyrin 22 was first converted into its iron(III) complex, and this was then heated in a resorcinol melt to accomplish protiodevinylation. ${ }^{10}$ Finally, removal of iron with $\mathrm{HCl} / \mathrm{methanol} / \mathrm{FeSO}_{4}$ afforded corallistin $\mathrm{E}$ methyl ester (5).

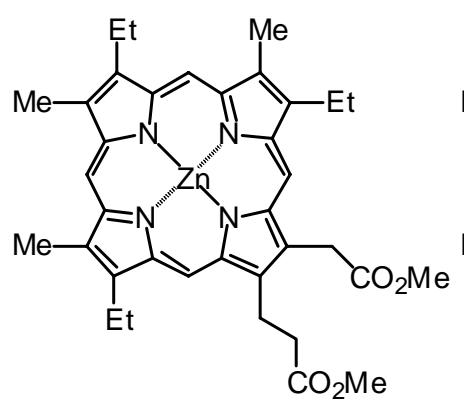

27

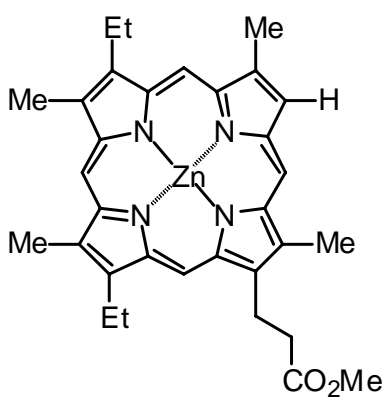

28

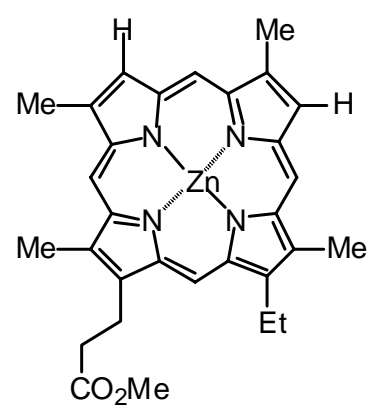

29

\section{Zinc(II) complexes of Corallistin B dimethyl ester, Corallistin C methyl ester, and Corallistin E methyl ester}

Pietra and coworkers ${ }^{2}$ reported NMR data for only the zinc(II) complexes of the natural corallistin esters 2, 3, and 5. Therefore, in order to have a comparison of the NMR data from the synthetic corallistins with those obtained from natural sources, we needed to prepare the zinc(II) complexes of the synthetic corallistins B (2), C (3), and E (5). Individually, corallistins B, C, and 
E were treated with zinc(II) acetate to give the corresponding zinc(II) complexes from which ${ }^{1} \mathrm{H}-$ NMR data were obtained.

The ${ }^{1} \mathrm{H}-\mathrm{NMR}$ data of synthetic zinc(II) corallistins B (27), C (28), and E (29) are listed in Tables 1, 2, and 3, respectively, along with the data from the corresponding natural zinc(II) corallistins reported by Pietra and coworkers. ${ }^{2}$

It should be mentioned that zinc(II) corallistin B dimethyl ester (27) (in $\mathrm{CDCl}_{3}$ ) gave a ${ }^{1} \mathrm{H}-\mathrm{NMR}$ spectrum having broadened signals, particularly those from the meso protons (broad singlets at $9.06 \mathrm{ppm}$ and $9.30 \mathrm{ppm}$ ) (Table 1). The broadening of the signals is probably a result of the aggregation of the porphyrin molecules. Porphyrin NMR spectroscopy is known to be solvent and concentration dependent since the porphyrin molecules can form aggregates in solution. ${ }^{11}$ Various degrees of aggregation often affect the NMR spectrum. To alleviate this problem, a donor molecule is often added to break up the aggregates. Therefore, in our case, the ${ }^{1} \mathrm{H}-\mathrm{NMR}$ spectrum of zinc(II) corallistin B dimethyl ester (27) was measured again with the compound in $\mathrm{CDCl}_{3}$ containing a small amount of pyridine- $\mathrm{d} 5$. All the signals were sharpened, but as a result of axial ligation with pyridine, the chemical shifts of the compound differed from those observed using $\mathrm{CDCl}_{3}$ alone. For example, the meso proton signals appeared as four singlets at 9.98, 9.99, 10.00, and 10.07 ppm, more downfield than the reported values (Table 1).

Table 1. ${ }^{1} \mathrm{H}-\mathrm{NMR}$ data from natural and synthetic zinc(II) corallistin B dimethyl ester (27)

\begin{tabular}{|c|c|c|}
\hline & \multicolumn{2}{|c|}{ Chemical shifts (ppm) in $\mathrm{CDCl}_{3}$ of zinc(II) complex of: } \\
\hline & Natural corallistin B dimethyl ester & Synthetic sample \\
\hline & 1.64 & $1.64(\mathrm{t})$ \\
\hline \multirow[t]{3}{*}{$3-, 8-$, and $17-\mathrm{CH}_{2} \underline{\mathrm{CH}}_{3}$} & 1.73 & $1.73(\mathrm{~m})$ \\
\hline & 1.74 & \\
\hline & 3.60 & \\
\hline \multirow[t]{3}{*}{$3-, 8-$, and $17-\mathrm{CH}_{2} \mathrm{CH}_{3}$} & 3.81 & $3.89 \& 3.97$ (overlapping q) \\
\hline & 3.87 & \\
\hline & 3.20 & $3.46(\mathrm{~s})$ \\
\hline \multirow[t]{2}{*}{$2-, 7-$, and $18-\mathrm{CH}_{3}$} & 3.34 & $3.47(\mathrm{~s})$ \\
\hline & 3.40 & $3.54(\mathrm{~s})$ \\
\hline $13-\mathrm{CH}_{2} \underline{\mathrm{C}}_{2} \mathrm{CO}_{2} \mathrm{CH}_{3}$ & 3.15 & $3.19(\mathrm{t})$ \\
\hline $13-\mathrm{CH}_{2} \mathrm{CH}_{2} \mathrm{CO}_{2} \mathrm{CH}_{3}$ & 4.19 & $4.27(\mathrm{t})$ \\
\hline $12-\mathrm{CH}_{2} \mathrm{CO}_{2} \mathrm{CH}_{3}$ & 4.81 & $4.83(\mathrm{~s})$ \\
\hline $13-\mathrm{CH}_{2} \mathrm{CH}_{2} \mathrm{CO}_{2} \mathrm{CH}_{3}$ and & 3.70 & $3.70(\mathrm{~s})$ \\
\hline \multirow[t]{2}{*}{$12-\mathrm{CH}_{2} \mathrm{CO}_{2} \mathrm{CH}_{3}$} & 3.76 & $3.74(\mathrm{~s})$ \\
\hline & 9.20 & \\
\hline \multirow[t]{3}{*}{$5-\underline{\mathrm{H}}, 10-\underline{\mathrm{H}}, 15-\underline{\mathrm{H}}$, and $20-\underline{\mathrm{H}}$} & 9.23 & $9.06(\mathrm{bs})^{*}$ \\
\hline & 9.35 & $9.30(\mathrm{bs})^{*}$ \\
\hline & 9.42 & ${ }^{*}$ see text \\
\hline
\end{tabular}


Surprisingly, aggregation of the porphyrin molecules did not seem to occur in the cases of zinc(II) corallistins $\mathrm{C}$ methyl ester (28) and E methyl ester (29). Their ${ }^{1} \mathrm{H}-\mathrm{NMR}\left(\mathrm{CDCl}_{3}\right)$ spectra appeared to be normal.

\section{Biosynthetic postulate for Corallistin(s) formation}

Jackson and coworkers showed that in heme metabolism in rats the biosynthetic transformation of uroporphyrinogen-III (30) into coproporphyrinogen-III (31) takes place in a stepwise manner through unique hepta- 32, hexa- 33, and penta-carboxylic 34 porphyrinogens (Scheme 4). ${ }^{12}$ Since Corallistins A and B both possess a 12-acetic side chain one might postulate that the corallistins as a whole or in part follow the same sequence, with a deviation from normal biosynthesis at the point of porphyrinogen 34 for corallistins A and B. This has also been postulated for the biosynthesis of many of the bacteriochlorophyll-c and $-\mathrm{d}$ homologues. ${ }^{13}$

Table 2. ${ }^{1} \mathrm{H}-\mathrm{NMR}$ data from natural and synthetic zinc(II) corallistin $\mathrm{C}$ methyl ester (28)

\begin{tabular}{ccc}
\hline & \multicolumn{2}{c}{ Chemical shifts (ppm) in $\mathrm{CDCl}_{3}$ of zinc(II) complex of: } \\
\cline { 2 - 3 } 3- and 17- $\mathrm{CH}_{2} \underline{\mathrm{CH}}_{3}$ & 1.71 & Synthetic sample \\
\cline { 2 - 3 } 3- and 17- $\underline{\mathrm{CH}}_{2} \mathrm{CH}_{3}$ & 1.76 & $1.76(\mathrm{~m})$ \\
& 3.76 & \\
& 3.87 & $3.82(\mathrm{q})$ \\
2-, 7-, 12-, and 18- $\underline{\mathrm{H}}_{3}$ & 3.33 & $3.92(\mathrm{q})$ \\
& 3.42 & $3.38(\mathrm{~s})$ \\
& 3.46 & $3.45(\mathrm{~s})$ \\
13- $\mathrm{CH}_{2} \underline{\mathrm{H}}_{2} \mathrm{CO}_{2} \mathrm{CH}_{3}$ & 3.60 & $3.48(\mathrm{~s})$ \\
13- $\underline{\mathrm{H}_{2}} \mathrm{CH}_{2} \mathrm{CO}_{2} \mathrm{CH}_{3}$ & 3.13 & $3.62(\mathrm{~s})$ \\
13- $\mathrm{CH}_{2} \mathrm{CH}_{2} \mathrm{CO}_{2} \mathrm{C}_{3}$ & 4.21 & $3.15(\mathrm{t})$ \\
$8-\underline{\mathrm{H}}$ & 3.71 & $4.24(\mathrm{t})$ \\
& 8.79 & $3.70(\mathrm{~s})$ \\
& 9.38 & $8.84(\mathrm{~s})$ \\
5- $\underline{\mathrm{H}}, 10-\underline{\mathrm{H}}, 15-\underline{\mathrm{H}}$, and $20-\underline{\mathrm{H}}$ & 9.43 & $9.48(\mathrm{~s})$ \\
& 9.44 & $9.51(\mathrm{~s})$ \\
& 9.49 & $9.53(\mathrm{~s})$ \\
& & $9.58(\mathrm{~s})$ \\
\hline
\end{tabular}


Table 3. ${ }^{1} \mathrm{H}-\mathrm{NMR}$ data from natural and synthetic zinc(II) corallistin E methyl ester (29)

\begin{tabular}{|c|c|c|}
\hline & \multicolumn{2}{|c|}{ Chemical shifts (ppm) in $\mathrm{CDCl}_{3}$ of zinc(II) complex of: } \\
\hline & Natural corallistin E methyl ester & Synthetic sample \\
\hline $17-\mathrm{CH}_{2} \underline{\mathrm{CH}}_{3}$ & 1.76 & $1.77(\mathrm{t})$ \\
\hline \multirow[t]{2}{*}{$17-\underline{C H}_{2} \mathrm{CH}_{3}$} & 3.89 & $3.91(q)$ \\
\hline & 3.29 & $3.35(\mathrm{~s})$ \\
\hline \multirow[t]{3}{*}{$2-, 7-, 12-$, and $18-\mathrm{CH}_{3}$} & 3.45 & $3.50(\mathrm{~s})$ \\
\hline & 3.47 & $3.52(\mathrm{~s})$ \\
\hline & 3.58 & $3.61(\mathrm{~s})$ \\
\hline $17-\mathrm{CH}_{2} \underline{\mathrm{CH}}_{2} \mathrm{CO}_{2} \mathrm{CH}_{3}$ & 3.04 & $3.07(\mathrm{t})$ \\
\hline $17-\mathrm{CH}_{2} \mathrm{CH}_{2} \mathrm{CO}_{2} \mathrm{CH}_{3}$ & 4.09 & $4.15(t)$ \\
\hline $17-\mathrm{CH}_{2} \mathrm{CH}_{2} \mathrm{CO}_{2} \underline{\mathrm{CH}}_{3}$ & 3.67 & $3.67(\mathrm{~s})$ \\
\hline \multirow[t]{3}{*}{$3-\underline{\mathrm{H}}$ and $8-\underline{\mathrm{H}}$} & 8.58 & $8.70(\mathrm{~s})$ \\
\hline & 8.77 & $8.84(\mathrm{~s})$ \\
\hline & 9.19 & $9.38(\mathrm{~s})$ \\
\hline \multirow[t]{3}{*}{$5-\underline{\mathrm{H}}, 10-\underline{\mathrm{H}}, 15-\underline{\mathrm{H}}$, and $20-\underline{\mathrm{H}}$} & 9.28 & $9.42(\mathrm{~s})$ \\
\hline & 9.39 & $9.52(\mathrm{~s})$ \\
\hline & 9.49 & $9.60(\mathrm{~s})$ \\
\hline
\end{tabular}

Corralistins C, D, and E are presumably formed from coproporphyrinogen-III (31). The ethyl groups at the 8-position in corallistin $\mathrm{A}$, at the 3-and 8-positions in corallistin $\mathrm{B}$, and at the 3position in corallistins $\mathrm{C}$ and $\mathrm{D}$ are presumably formed from the propionic acid side chain via the proposed normal biosynthetic sequence (common with formation of the 8-ethyl in chlorophyll-a) of hydroxylation (in oxygenic organisms) to give $\mathbf{3 5}$ followed by decarboxylative dehydration to give 36 and reduction of the vinyl to give ethyl (as in 37) (Scheme 5). ${ }^{14}$ The unsubstituted positions (at 3- and/or 8 in corallistins A, C, D and E) may be produced by some form of devinylation reaction (for which there is at least a chemical precedent). ${ }^{10}$ Finally, it is not clear how the 13- and 17-ethyl groups in corallistins A, B, C and E are produced, but this may well happen also as shown in Scheme 5.

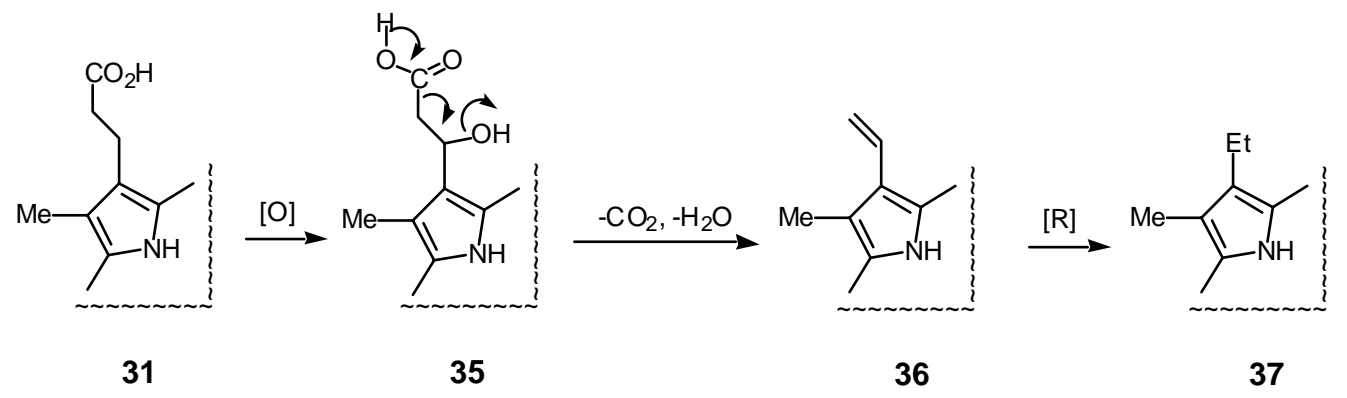

Scheme 5. Proposed biosynthetic transformation of propionic acid into ethyl side chains. 


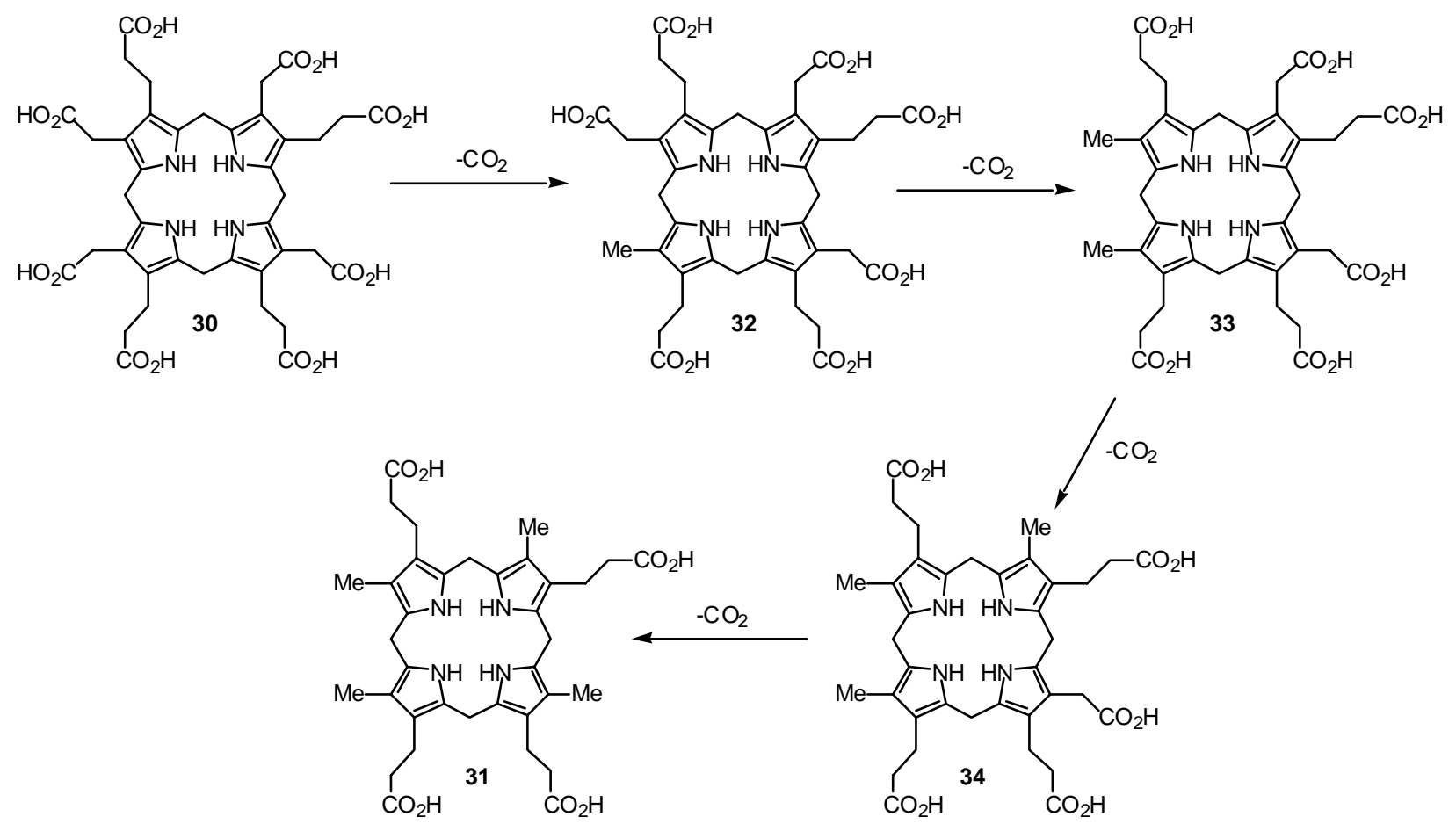

Scheme 4. Biosynthesis of coproporphyrinogen-III (31) via uroporphyrinogen-III (30) in Rats. ${ }^{10}$

\section{Experimental Section}

General Procedures. Melting points were measured on a Thomas/Bristoline microscopic hotstage apparatus and are uncorrected. Electronic absorption spectra were measured on a HewlettPackard 8450A spectrophotometer using solutions in dichloromethane. Proton NMR spectra were recorded at $300 \mathrm{MHz}$ using a QE-300 spectrometer, with chemical shifts in parts per million (ppm). Elemental analyses were performed by the Microanalytical Laboratory at the University of California, Berkeley. All reactions were monitored by thin layer chromatography and were performed on cut strips (Merck silica gel 60 F254 precoated $(0.25 \mathrm{~mm}$ thickness) plastic-backed sheets. For column chromatography two types of packing media were generally employed; pyrroles and dipyrromethanes were usually chromatographed on Merck silica gel 60, whereas porphyrins were purified over Merck natural alumina [70-230 mesh; Brockmann Grade III (6\% water)].

Dibenzyl 3-Ethyl-8-(2-methoxycarbonylethyl)-7-methoxycarbonylmethyl-2-methyldipyrromethane-1,9-dicarboxylate (9). Benzyl 4-ethyl-3-methylpyrrole-2-carboxylate (7) ${ }^{15}$ (140 mg, $0.575 \mathrm{mmol}$ ) and benzyl 5-acetoxymethyl-3-(2-methoxycarbonylethyl)-4-methoxycarbonylmethylpyrrole-2-carboxylate $(\mathbf{8})^{16}(250 \mathrm{mg}, 0.579)$ were dissolved in $\mathrm{CH}_{2} \mathrm{Cl}_{2}(60 \mathrm{~mL})$. Montmorillonite K10 clay (1.25 g) was added and the suspension was stirred at room 
temperature under $\mathrm{N}_{2}$ for $24 \mathrm{~h}$. The clay was filtered and the solvent of the filtrate was removed. The brown oil was chromatographed on a silica gel flash column eluting with ethyl acetate/cyclohexane (30/70) to afford the title compound as a light brown oil (194 mg, 55\%). ${ }^{1} \mathrm{H}-$ NMR $\left(\mathrm{CDCl}_{3}\right): \delta 1.04(\mathrm{t}, 3 \mathrm{H}), 2.29(\mathrm{~s}, 3 \mathrm{H}), 2.41$ (q, $\left.2 \mathrm{H}\right), 2.49,2.99$ (each t, $\left.2 \mathrm{H}\right), 3.47(\mathrm{~s}, 2 \mathrm{H})$, 3.60, 3.63 (each s, $3 \mathrm{H}), 3.83$ (s, $2 \mathrm{H}), 5.24,5.25$ (each s, $2 \mathrm{H}), 7.33$ (m, $10 \mathrm{H}), 8.77,8.28$ (each bs, $1 \mathrm{H})$.

9-tert-Butoxycarbonyl-7-ethyl-3,8-dimethyldipyrromethane-1-carboxylic acid (15). tertButyl 5-acetoxymethyl-4-ethyl-3-methylpyrrole-2-carboxylate (12) ${ }^{17}(900 \mathrm{mg}, 3.19 \mathrm{mmol})$ and benzyl 4-methylpyrrole-2-carboxylate (13) ${ }^{18}$ (690 mg, $3.21 \mathrm{mmol}$ ) were dissolved in $\mathrm{CH}_{2} \mathrm{Cl}_{2}$ $(50 \mathrm{~mL})$. To this solution was added Montmorillonite $\mathrm{K} 10$ clay $(5.0 \mathrm{~g})$. The resulting suspension was stirred at room temperature under argon. After $14 \mathrm{~h}$, the suspension was filtered to removed the clay, and the filtrate was evaporated to give benzyl 9-tert-butoxycarbonyl-7-ethyl-3,8dimethyldipyrromethane-1-carboxylate (14) as a brown oil (1.32 g), which was dissolved in THF $(100 \mathrm{~mL})$. To this solution were added $10 \% \mathrm{Pd} / \mathrm{C}(130 \mathrm{mg})$ and triethylamine (2 drops). The resulting suspension was stirred at room temperature under $\mathrm{H}_{2}$ at atmospheric pressure (balloon) overnight. The Pd-C was filtered and the filtrate was evaporated to afford a solid which was shown by ${ }^{1} \mathrm{H}-\mathrm{NMR}$ to be a mixture of the title compound and a small amount of the decarboxylated product, tert-butyl 3-ethyl-2,7-dimethyldipyrro-methane-1-carboxylate. This mixture was therefore used in the subsequent reaction without further purification.

tert-Butyl 12-Ethyl-2-(2-methoxycarbonylethyl)-1,3,7,8,13-pentamethyl-tripyrrin-a-14carboxylate hydrobromide (17). 9-tert-Butoxycarbonyl-7-ethyl-3,8-dimethyldipyrromethane-1carboxylic acid (15) (crude, $610 \mathrm{mg}, 1.76 \mathrm{mmol}$ ) and 2-formyl-4-(2-methoxycarbonylethyl)-3,5dimethylpyrrole (16) ${ }^{19}$ (370 mg, $\left.1.77 \mathrm{mmol}\right)$ were dissolved in $\mathrm{CH}_{2} \mathrm{Cl}_{2}(20 \mathrm{~mL})$. A solution of ptoluenesulfonic acid $(600 \mathrm{mg})$ in methanol $(10 \mathrm{~mL})$ was added and the reaction mixture was stirred at room temperature for $2 \mathrm{~h}$. It was then washed with water, dried (anhy. $\mathrm{Na}_{2} \mathrm{SO}_{4}$ ), and the solvent was removed to give a residue. The residue was dissolved in dry $\mathrm{CH}_{2} \mathrm{Cl}_{2}$ and $\mathrm{HBr}$ gas was bubbled into the solution briefly before ether was added. The resulting precipitate was collected and washed with ether. ${ }^{1} \mathrm{H}-\mathrm{NMR}$ spectroscopy showed that this precipitate was substantially the title tripyrrin hydrobromide salt $17(750 \mathrm{mg})$ with a slight contamination of the a,c-biladiene dihydrobromide salt formed from cleavage of tert-butyl ester and subsequent reaction with formylpyrrole 16. This mixture was used in the next reaction without further purification.

Benzyl 7,12-Bis(2-chloroethyl)-2-ethyl-1,3,8,13-tetramethyltripyrrin-a-14-carboxylate hydrobromide (24). Benzyl 9-tert-butoxycarbonyl-3,8-bis(2-chloroethyl)-2,7-dimethyldipyrromethane-1carboxylate $(23)^{20}(824 \mathrm{mg}, 1.65 \mathrm{mmol})$ was stirred in TFA $(5 \mathrm{~mL})$ for $5 \mathrm{~min}$ before 4-ethyl-2formyl-3,5-dimethylpyrrole $(\mathbf{1 8})^{21}(251 \mathrm{mg}, 1.66 \mathrm{mmol})$ in methanol $(25 \mathrm{~mL})$ was added. The reaction mixture was stirred at room temperature for $1.5 \mathrm{~h}$. It was then cooled in an ice bath, and $30 \% \mathrm{HBr}$ /acetic acid was added, followed by addition of ether. The solid formed was collected and washed with ether to afford the title compound (778 $\mathrm{mg}, 73 \%), \mathrm{mp}>250{ }^{\circ} \mathrm{C}$. ${ }^{1} \mathrm{H}-\mathrm{NMR}$ $\left(\mathrm{CDCl}_{3}\right): \delta 1.07$ (t, $\left.3 \mathrm{H}\right), 2.06,2.26,2.27,2.70$ (each s, $\left.3 \mathrm{H}\right), 2.43$ (q, $2 \mathrm{H}$ ), 2.93, 3.10, 3.37, 3.63 
(each t, $2 \mathrm{H}), 4.33$ (s, $2 \mathrm{H}), 5.30(\mathrm{~s}, 2 \mathrm{H}), 7.10(\mathrm{~s}, 1 \mathrm{H}), 7.3-7.5(\mathrm{~m}, 5 \mathrm{H}), 10.63,11.10,11.23$ (each bs, $1 \mathrm{H}$ ). Anal. Calcd for $\mathrm{C}_{32} \mathrm{H}_{38} \mathrm{BrCl}_{2} \mathrm{~N}_{3} \mathrm{O}_{2} \cdot 0.5 \mathrm{H}_{2} \mathrm{O}: \mathrm{C}, 58.55 ; \mathrm{H}, 5.99 ; \mathrm{N}, 6.40$. Found: $\mathrm{C}$, $58.63 ; \mathrm{H}, 5.72 ; \mathrm{N}, 6.73$.

8,13-Bis(2-chloroethyl)-18-ethyl-2-(2-methoxycarbonylethyl)-1,3,7,12,17,19-hexamethyl-a,cbiladiene dihydrobromide (25). Benzyl 7,12-bis(2-chloroethyl)-2-ethyl-1,3,8,13-tetramethyltripyrrin-a-14-carboxylate hydrobromide (24) $(750 \mathrm{mg}, 1.16 \mathrm{mmol}$ ) was stirred in $30 \%$ $\mathrm{HBr} /$ acetic acid $(5 \mathrm{~mL})$ and TFA $(10 \mathrm{~mL})$ at room temperature for $6 \mathrm{~h}$ before addition of 2formyl-4-(2-methoxycarbonylethyl)-3,5-dimethylpyrrole $(\mathbf{1 6})^{19}$ in methanol $(25 \mathrm{~mL})$. The reaction mixture was stirred for $30 \mathrm{~min}$ at room temperature, followed by dropwise addition of ether. The resulting solid was collected and washed with ether to afford the title compound (500 $\mathrm{mg}, 55 \%), \mathrm{mp}>250{ }^{\circ} \mathrm{C} .{ }^{1} \mathrm{H}-\mathrm{NMR}\left(\mathrm{CDCl}_{3}\right): \delta 1.10(\mathrm{t}, 3 \mathrm{H}), 2.01,2.33,2.34,2.35$ (each s, $3 \mathrm{H}$ ), $2.50(\mathrm{~m}, 4 \mathrm{H}), 2.77$ (s, $6 \mathrm{H}), 2.80(\mathrm{t}, 2 \mathrm{H}), 3.00,3.10,3.50,3.60$ (each t, $2 \mathrm{H}), 3.70(\mathrm{~s}, 3 \mathrm{H}), 5.26$ $(\mathrm{s}, 2 \mathrm{H}), 7.13,7.15$ (each s, $1 \mathrm{H}), 13.33,13.50$ (each bs, $2 \mathrm{H}$ ). Anal. Calcd for $\mathrm{C}_{35} \mathrm{H}_{46} \mathrm{Br}_{2} \mathrm{Cl}_{2} \mathrm{~N}_{4} \mathrm{O}_{2} \cdot 0.5 \mathrm{H}_{2} \mathrm{O}: \mathrm{C}, 52.92 ; \mathrm{H}, 5.96 ; \mathrm{N}, 7.05$. Found: C, 52.80; H, 5.67; N, 7.09.

\section{3,8-Bis(2-chloroethyl)-13-ethyl-17-(2-methoxycarbonylethyl)-2,7,11,18-tetramethylporphyrin}

(26). Copper(II) acetate monohydrate $(2.20 \mathrm{~g}, 11.0 \mathrm{mmol})$ and DMF $(30 \mathrm{~mL})$ were mixed and heated to $140{ }^{\circ} \mathrm{C}$ under argon. $a, c$-Biladiene (25) $(425 \mathrm{mg}, 0.551 \mathrm{mmol})$ was then added directly to the copper(II) acetate/DMF solution. The reaction mixture was heated at $140{ }^{\circ} \mathrm{C}$ under argon for $5 \mathrm{~min}$. It was allowed to cool to room temperature and was then diluted with $\mathrm{CH}_{2} \mathrm{Cl}_{2}$, washed twice with water, dried (anhy. $\mathrm{Na}_{2} \mathrm{SO}_{4}$ ), and the solvent was removed. The solid was dissolved in $15 \% \mathrm{H}_{2} \mathrm{SO}_{4} / \mathrm{TFA}(20 \mathrm{~mL})$ and stirred for $1 \mathrm{~h}$ at room temperature under argon. It was then poured into iced water and extracted with $\mathrm{CH}_{2} \mathrm{Cl}_{2}$ several times. The combined organic phases were washed with sat. $\mathrm{NaHCO}_{3}$ solution $\left(2 \mathrm{x}\right.$ ), brine, dried (anhy. $\mathrm{Na}_{2} \mathrm{SO}_{4}$ ), and the solvent was removed. The solid residue was chromatographed on a silica gel flash column eluting with $1 \%$ $\mathrm{MeOH} / \mathrm{CH}_{2} \mathrm{Cl}_{2}$ to afford the title porphyrin (106 mg, 32\%), mp 234-236 ${ }^{\circ} \mathrm{C}$. UV-Vis $\left(\mathrm{CH}_{2} \mathrm{Cl}_{2}\right)$ : $\lambda_{\max } 400 \mathrm{~nm}$ (E138 900), 498 (20 400), 532 (17 200), 568 (14 800), 620 (13 000). ${ }^{1} \mathrm{H}-\mathrm{NMR}$ $\left(\mathrm{CDCl}_{3}\right): \delta-3.77$ (bs, $\left.2 \mathrm{H}\right), 1.89$ (t, $\left.3 \mathrm{H}\right), 3.27$ (t, $\left.2 \mathrm{H}\right), 3.65-3.67$ (overlapping s, $15 \mathrm{H}$ ), 4.13 (q, 2 H), 4.32 (t, $4 \mathrm{H}), 4.40$ (t, $2 \mathrm{H}), 4.51,4.52$ (each t, $2 \mathrm{H}$ ), 10.00, 10.01, 10.08, 10.10 (each s, $1 \mathrm{H}$ ). HRMS: Calcd for $\mathrm{C}_{34} \mathrm{H}_{38} \mathrm{Cl}_{2} \mathrm{~N}_{4} \mathrm{O}_{2}$ : 604.2372. Found: 604.2382. Anal. Calcd for $\mathrm{C}_{34} \mathrm{H}_{38} \mathrm{Cl}_{2} \mathrm{~N}_{4} \mathrm{O}_{2}$ : C, 67.43; H, 6.32; N, 9.25. Found: C, 67.28; H, 6.28; N, 9.15.

3,8-Diethenyl-13-ethyl-17-(2-methoxycarbonylethyl)-2,7,11,18-tetramethylporphyrin (22). Porphyrin $26(95 \mathrm{mg}, 0.157 \mathrm{mmol})$ in pyridine $(75 \mathrm{~mL})$ was heated at reflux under argon for 30 min. Water $(12 \mathrm{~mL})$ was added and the mixture was stirred at $105{ }^{\circ} \mathrm{C}$ for $5 \mathrm{~min}$ before the addition of $3 \%$ aqueous $\mathrm{KOH}(15 \mathrm{~mL})$. The reaction mixture was then stirred at $105{ }^{\circ} \mathrm{C}$ under argon for $2.5 \mathrm{~h}$. After cooling, it was diluted with $\mathrm{CH}_{2} \mathrm{Cl}_{2}$ and THF, washed with $2 \mathrm{~N} \mathrm{HCl}(3 \mathrm{x})$, dried (anhy $\mathrm{Na}_{2} \mathrm{SO}_{4}$ ), and the solvent was then removed. The residue was dissolved in $5 \%$ $\mathrm{H}_{2} \mathrm{SO}_{4} /$ methanol $(100 \mathrm{~mL})$ and stirred under argon at room temperature overnight. It was diluted with $\mathrm{CH}_{2} \mathrm{Cl}_{2}$, washed with water, brine, dried (anhy. $\mathrm{Na}_{2} \mathrm{SO}_{4}$ ), and the solvent was removed to give a dark brown solid, which was chromatographed on a silica gel flash column eluting with $\mathrm{CH}_{2} \mathrm{Cl}_{2}$. The red eluates were evaporated to dryness and the residue was recrystallized from 
$\mathrm{CH}_{2} \mathrm{Cl}_{2} / \mathrm{n}$-hexane to afford the title porphyrin (41 mg, 49\%), mp $>250{ }^{\circ} \mathrm{C}$. UV-Vis $\left(\mathrm{CH}_{2} \mathrm{Cl}_{2}\right)$ : $\lambda_{\max } 406 \mathrm{~nm}$ ( $\varepsilon 165$ 000), 506 (21 900), 540 (19 500), 574 (14 700), 628 (12 900). ${ }^{1} \mathrm{H}-\mathrm{NMR}$ $\left(\mathrm{CDCl}_{3}\right): \delta-3.65(\mathrm{bs}, 2 \mathrm{H}), 1.87(\mathrm{t}, 3 \mathrm{H}), 3.26(\mathrm{t}, 2 \mathrm{H}), 3.62,3.68,3.73,3.74,3.75$ (each s, $\left.3 \mathrm{H}\right)$, 4.08 (q, 2 H), 4.39 (t, 2 H), 6.18, 6.37 (each dd, 2 H), 8.30 (m, 2 H), 10.02, 10.09, 10.18, 10.23 (each s, $1 \mathrm{H}$ ). Anal. Calcd for $\mathrm{C}_{34} \mathrm{H}_{36} \mathrm{~N}_{4} \mathrm{O}_{2} \cdot \mathrm{H}_{2} \mathrm{O}: \mathrm{C}, 74.16 ; \mathrm{H}, 6.96 ; \mathrm{N}, 10.17$. Found: $\mathrm{C}, 74.51 ; \mathrm{H}$, $6.94 ; \mathrm{N}, 10.03$.

3,8,17-Triethyl-13-(2-methoxycarbonylethyl)-12-methoxycarbonylmethyl-2,7,18-trimethylporphyrin (Corallistin B dimethyl ester) (2). Dibenzyl 3-ethyl-8-(2-methoxycarbonylethyl)-7methoxycarbonylmethyl-2-methyl-dipyrromethane-1,9-dicarboxylate (9) (334 mg, $0.543 \mathrm{mmol}$ ) was dissolved in THF $(150 \mathrm{~mL}) .10 \% \mathrm{Pd} / \mathrm{C}(70 \mathrm{mg})$ and triethylamine ( 2 drops) were added. The suspension was stirred at room temperature under hydrogen at atmospheric pressure (balloon). After $16 \mathrm{~h}$, the $\mathrm{Pd} / \mathrm{C}$ was removed by filtration, and the filtrate was evaporated to give dipyrromethane dicarboxylic acid (11), which was suspended in $\mathrm{CH}_{2} \mathrm{Cl}_{2}(50 \mathrm{~mL})$. To this suspension p-toluenesulfonic acid $(1.0 \mathrm{~g})$ in methanol $(15 \mathrm{~mL})$ was added, and the resulting mixture was stirred at room temperature under argon for $10 \mathrm{~min}$ before the addition of 2,8diethyl-1,9-diformyl-3,7-dimethyldipyrromethane $(\mathbf{1 0})^{21}(170 \mathrm{mg}, 0.570 \mathrm{mmol})$. This reaction mixture was stirred overnight and a saturated solution of zinc(II) acetate in methanol (10 mL) was then added. Stirring was continued at room temperature in open air for $1 \mathrm{~d}$. The solvent was evaporated and the residue was stirred in TFA $(10 \mathrm{~mL})$ for $10 \mathrm{~min}$ before being diluted with $\mathrm{CH}_{2} \mathrm{Cl}_{2}$, washed with water, saturated sodium bicarbonate solution, brine, dried (anhy. $\mathrm{Na}_{2} \mathrm{SO}_{4}$ ), and the solvent was removed to give a residue. The residue was chromatographed on an alumina (Brockmann Grade III) column eluting with $\mathrm{CH}_{2} \mathrm{Cl}_{2}$ to give the desired porphyrin as a red solid (96 mg, 30\%), mp 216-218 ${ }^{\circ} \mathrm{C}$. UV-Vis $\left(\mathrm{CH}_{2} \mathrm{Cl}_{2}\right): \lambda_{\max } 400 \mathrm{~nm}$ ( 126300$), 500$ (14 500), 534 (12 500), 566 (10 000), 620 (7700). ${ }^{1} \mathrm{H}-\mathrm{NMR}\left(\mathrm{CDCl}_{3}\right)$ : $\quad-3.76$ (bs, $\left.2 \mathrm{H}\right), 1.89$ (overlapping t, 9 $\mathrm{H}), 3.35(\mathrm{t}, 2 \mathrm{H}), 3.58,3.60,3.61,3.70,3.73$ (each s, $3 \mathrm{H}$ ), 4.03-4.12 (overlapping q, $6 \mathrm{H}$ ), 4.45 (t, $2 \mathrm{H}), 5.11(\mathrm{~s}, 2 \mathrm{H}), 10.07$ (s, $2 \mathrm{H}), 10.11,10.18$ (each s, $1 \mathrm{H}$ ). HRMS Calcd for $\mathrm{C}_{36} \mathrm{H}_{42} \mathrm{~N}_{4} \mathrm{O}_{4}$ : 594.3206. Found: 594.3221. Anal. Calcd for $\mathrm{C}_{36} \mathrm{H}_{42} \mathrm{~N}_{4} \mathrm{O}_{4}$ : C, 72.70; H, 7.12; N, 9.42. Found: C, 72.49; H, 7.18; N, 9.26.

3,17-Diethyl-13-(2-methoxycarbonylethyl)-2,7,12,18-tetramethylporphyrin (Corallistin C methyl ester) (3). tert-Butyl 12-ethyl-2-(2-methoxycarbonylethyl)-1,3,7,8,13-pentamethyltripyrrin-a-14-carboxylate hydrobromide (17) (crude, $518 \mathrm{mg}, 0.902 \mathrm{mmol}$ ) was treated with TFA $(5 \mathrm{~mL})$ at room temperature for $15 \mathrm{~min}$ before a solution of 4-ethyl-2-formyl-3,5dimethylpyrrole $(\mathbf{1 8})^{22}(151 \mathrm{mg}, 0.999 \mathrm{mmol})$ in methanol $(10 \mathrm{~mL})$ was added. The resulting mixture was stirred at room temperature for $1.5 \mathrm{~h}$. $\mathrm{HBr}$ gas was bubbled in briefly, followed by the addition of ether. The precipitated $a, c$-biladiene dihydrobromide salt 19 was collected and washed with ether. This salt was added to a preheated $\left(140{ }^{\circ} \mathrm{C}\right)$ solution of $\mathrm{Cu}(\mathrm{OAc})_{2} \cdot \mathrm{H}_{2} \mathrm{O}(2.0 \mathrm{~g})$ in DMF $(20 \mathrm{~mL})$. The mixture was stirred at $140{ }^{\circ} \mathrm{C}$ for $5 \mathrm{~min}$ before being allowed to cool to room temperature. It was then diluted with $\mathrm{CH}_{2} \mathrm{Cl}_{2}$, washed with water (2x), dried (anhy. $\mathrm{Na}_{2} \mathrm{SO}_{4}$ ), and the solvent was removed to give the crude copper(II) porphyrin 20. This porphyrin was stirred in $15 \% \mathrm{H}_{2} \mathrm{SO}_{4} / \mathrm{TFA}(15 \mathrm{~mL})$ for $1 \mathrm{~h}$ at room temperature before being poured into 
iced water. After the ice had melted, the solution was extracted with $\mathrm{CH}_{2} \mathrm{Cl}_{2}$ several times. The combined organic layer was washed with saturated sodium bicarbonate solution, brine, dried (anhy. $\mathrm{Na}_{2} \mathrm{SO}_{4}$ ), and the solvent was removed to give a dark brown residue. The residue was chromatographed on silica gel preparative TLC plates eluting with $1 \%$ methanol/ $\mathrm{CH}_{2} \mathrm{Cl}_{2}$ to afford the title porphyrin $3(30 \mathrm{mg})$, mp 192-194 ${ }^{\circ} \mathrm{C}$. UV-Vis $\left(\mathrm{CH}_{2} \mathrm{Cl}_{2}\right): \lambda_{\max } 399 \mathrm{~nm}(120$ 000), 496 (18 900), 530 (15 900), 566 (14 100), 618 (12 380). ${ }^{1} \mathrm{H}-\mathrm{NMR}\left(\mathrm{CDCl}_{3}\right): \delta$-3.78 (bs, 2 $\mathrm{H}), 1.87$ (overlapping t, $6 \mathrm{H}$ ), 3.27 (t, $2 \mathrm{H}), 3.67,3.68,3.70$, 3.72, 3.75 (each s, $3 \mathrm{H}), 4.06$ (m, 4 H), $4.34(\mathrm{t}, 2 \mathrm{H}), 9.04(\mathrm{~s}, 1 \mathrm{H}), 10.02,10.07,10.10,10.12$ (each s, $1 \mathrm{H})$. HRMS Calcd for $\mathrm{C}_{32} \mathrm{H}_{36} \mathrm{~N}_{4} \mathrm{O}_{2}: 508.2838$. Found: 508.2831.

13-Ethyl-17-(2-methoxycarbonylethyl)-2,7,12,18-tetramethylporphyrin (Corallistin E methyl ester) (5). $\mathrm{FeCl}_{2} \cdot 4 \mathrm{H}_{2} \mathrm{O}(250 \mathrm{mg})$ in degassed acetonitrile $(20 \mathrm{~mL})$ was heated to $70{ }^{\circ} \mathrm{C}$ under argon before 3,8-diethenyl-13-ethyl-17-(2-methoxycarbonylethyl)-2,7,11,18-tetramethylporphyrin (22) (38 mg, $0.072 \mathrm{mmol})$ in degassed $\mathrm{CHCl}_{3}(12 \mathrm{~mL})$ was added dropwise over a period of $10 \mathrm{~min}$. Heating at $70{ }^{\circ} \mathrm{C}$ was continued for $2 \mathrm{~h}$. The mixture was then allowed to cool, diluted with $\mathrm{CH}_{2} \mathrm{Cl}_{2}$, washed with $2 \mathrm{~N} \mathrm{HCl}(2 \mathrm{x})$, brine, dried (anhy. $\mathrm{Na}_{2} \mathrm{SO}_{4}$ ), and the solvent was removed to give a dark brown residue. The residue was mixed with resorcinol (140 $\mathrm{mg}$ ) and the mixture was heated at $180{ }^{\circ} \mathrm{C}$ for $40 \mathrm{~min}$. It was then allowed to cool before ether was carefully added. The solid formed was collected and washed with ether until the washing was almost clear. This solid was mixed with a saturated solution of $\mathrm{FeSO}_{4}$ in methanol $(15 \mathrm{~mL})$, followed the addition of pyridine $(5 \mathrm{~mL})$. The mixture was cooled in an ice bath before $\mathrm{HCl}$ gas was bubbled into the mixture for $30 \mathrm{~min}$. It was then poured into iced water, and the resulting solution was extracted with $\mathrm{CH}_{2} \mathrm{Cl}_{2}(2 \mathrm{x})$. The combined organic layer was washed with water, brine, dried (anhy. $\mathrm{Na}_{2} \mathrm{SO}_{4}$ ), and the solvent was removed to give a residue. The residue was chromatographed on an alumina (Brockmann Grade III) column eluting with $\mathrm{CH}_{2} \mathrm{Cl}_{2}$ to afford the title porphyrin 5 (7 mg), mp 204-206 ${ }^{\circ} \mathrm{C}$. UV-Vis $\left(\mathrm{CH}_{2} \mathrm{Cl}_{2}\right): \lambda_{\max } 398$ ( $\varepsilon 131$ 100), 496 (17 300), 530 (14 100), 564 (12 700), 618 (9900). ${ }^{1} \mathrm{H}-\mathrm{NMR}\left(\mathrm{CDCl}_{3}\right): \delta-3.82(\mathrm{bs}, 2 \mathrm{H}), 2.01$ (t, $\left.3 \mathrm{H}\right)$, 3.27 (t, 2 H), 3.63, 3.65, 3.67, 3.73, 3.77 (each s, 3 H), 4.11 (q, 2 H), 4.39 (t, 2 H), 9.07, 9.13 (each s, $1 \mathrm{H}$ ), 10.01, 10.08, 10.08, 10.15 (each s, $1 \mathrm{H}$ ). HRMS Calcd for $\mathrm{C}_{30} \mathrm{H}_{32} \mathrm{~N}_{4} \mathrm{O}_{2}: 480.2525$. Found: 480.2534 .

Zinc(II) 3,8,17-triethyl-13-(2-methoxycarbonylethyl)-12-methoxy-carbonylmethyl-2,7,18trimethylporphyrin (27). Porphyrin (2) $(10 \mathrm{mg}, 0.017 \mathrm{mmol})$ was dissolved in $\mathrm{CHCl}_{3}(3 \mathrm{~mL})$ and saturated $\mathrm{Zn}(\mathrm{OAc})_{2} /$ methanol $(2 \mathrm{~mL})$ was added. The mixture was heated at reflux under argon for $1 \mathrm{~h}$ before being diluted with $\mathrm{CHCl}_{3}$. It was then washed with water, dried (anhy. $\mathrm{Na}_{2} \mathrm{SO}_{4}$ ), and the solvent was removed to afford the titled compound (6 mg, 55\%). UV-Vis $\left(\mathrm{CH}_{2} \mathrm{Cl}_{2}\right): \lambda_{\max }$ (rel. abs.) $398 \mathrm{~nm}(1.00), 529(0.08), 568(0.09) .{ }^{1} \mathrm{H}-\mathrm{NMR}\left(\mathrm{CDCl}_{3}\right): \delta 1.64$ (t, 3 $\mathrm{H}), 1.73(\mathrm{~m}, 6 \mathrm{H}), 3.46,3.47,3.54$ (each s, $3 \mathrm{H}$ ), 3.89, 3.97 (overlapping q, $6 \mathrm{H}$ ), 3.19, 4.27 (each t, 2 H), 3.70, 3.74 (each s, 3 H), 4.83 (s, $2 \mathrm{H}$ ), 9.06, 9.30 (each bs, $2 \mathrm{H}$ ).

Zinc(II) 3,17-diethyl-13-(2-methoxycarbonylethyl)-2,7,12,18-tetramethyl-porphyrin (28). This compound was prepared from porphyrin (3) $(5 \mathrm{mg}, 0.009 \mathrm{mmol})$ using the procedure described for the preparation of zinc(II) porphyrin 27. The amount of the title compound 
obtained was $3 \mathrm{mg}(60 \%)$. UV-Vis $\left(\mathrm{CH}_{2} \mathrm{Cl}_{2}\right): \lambda_{\max }$ (rel. abs.) $394 \mathrm{~nm}(1.00), 528(0.06), 565$ (0.07). ${ }^{1} \mathrm{H}-\mathrm{NMR}\left(\mathrm{CDCl}_{3}\right): \delta 1.76(\mathrm{~m}, 6 \mathrm{H}), 3.38,3.45,3.48,3.62$ (each s, $\left.3 \mathrm{H}\right), 3.82,3.92$ (each q, 4 H), 3.15, 4.24 (each t, 2 H), 3.70 (s, 3 H), 8.84 (s, 1 H), 9.48, 9.51, 9.53, 9.58 (each s, 1 H). Zinc(II) 13-ethyl-17-(2-methoxycarbonylethyl)-2,7,12,18-tetramethyl-porphyrin (29). This compound was prepared from porphyrin (5) $(5 \mathrm{mg}, 0.010 \mathrm{mmol})$ using the procedure described for the preparation of zinc(II) porphyrin 27. The amount of the title compound obtained was 4 $\mathrm{mg}(80 \%)$. UV-Vis $\left(\mathrm{CH}_{2} \mathrm{Cl}_{2}\right): \lambda_{\max }$ (rel. abs.) 393nm (1.00), $528(0.07), 564$ (0.08). ${ }^{1} \mathrm{H}-\mathrm{NMR}$ $\left(\mathrm{CDCl}_{3}\right): \delta 1.77(\mathrm{~m}, 6 \mathrm{H}), 3.35,3.50,3.52,3.61$ (each s, $\left.3 \mathrm{H}\right), 3.67$ (s, $\left.3 \mathrm{H}\right), 3.91$ (q, $\left.2 \mathrm{H}\right), 3.07$, 4.15 (each t, 2 H), 8.70, 8.84 (each s, $1 \mathrm{H}$ ), 9.38, 9.42, 9.52, 9.60 (each s, $1 \mathrm{H}$ ).

\section{Acknowledgments}

This research was supported by grants from the National Institutes of Health (HL 22252) and Oncologic Foundation of Buffalo.

\section{References}

1. D'Ambrosio, M.; Guerriero, A.; Debitus, C.; Ribes, O.; Richer de Forges, B.; Pietra, F. Helv. Chim. Acta 1989, 72, 1451.

2. D'Ambrosio, M.; Guerriero, A.; Debitus, C.; Ribes, O.; Pietra, F. Helv. Chim. Acta 1993, 76, 1489.

3. Yon-Hin, P.; Scott, A. I. Tetrahedron Lett. 1991, 32, 4231.

4. Miller, M.; Rapoport, H. J. Am. Chem. Soc. 1977, 99, 3479.

5. Parish, D. W. Ph. D. Dissertation, University of California, Davis, 1984.

6. Preliminary communication: Pandey, R. K.; Leung, S. H.; Smith, K. M. Tetrahedron Lett. 1994, 35, 8093.

7. Arsenault, G. P.; Bullock, E.; MacDonald, S. F.; J. Am. Chem. Soc. 1960, 82, 4384.

8. Smith, K. M. In The Porphyrin Handbook; Kadish, K. M.; Smith, K. M.; Guilard, R. Eds; Academic Press: Boston, 2000; Vol. 1; pp 13-14.

9. Smith, K. M. In The Porphyrin Handbook; Kadish, K. M.; Smith, K. M.; Guilard, R. Eds; Academic Press: Boston, 2000; Vol. 1; pp 119-148.

10. (a) Schumm, O. Z. Physiol. Chem. 1928, 178, 1. (b) Burbidge, P. A.; Collier, G. L.; Jackson, A. H.; Kenner, G. W. J. Chem. Soc. B 1967, 930. (c) Kenner, G. W.; Quirke, J. M. E.; Smith, K. M. Tetrahedron 1976, 32, 2753. (d) Bonnett, R.; Campion-Smith, I. H.; Page, A. J. J. Chem. Soc., Perkin Trans. 1 1977, 68. (e) DiNello, R. K.; Dolphin, D. H. J. Org. Chem. 1981, 46, 3498.

11. Abraham, R. J.; Pearson, H.; Smith, K. M. J. Am. Chem. Soc. 1976, 98, 1604. 
12. Jackson, A. H.; Sancovich, H. A.; Ferramola de Sancovich, A. M. Bioorg. Chem. 1980, 9, 71.

13. (a) Kenner, G. W., Rimmer, J.; Smith, K. M.; Unsworth, J. F. Phil. Trans. Roy. Soc. (London), 1976, 273B, 255. (b) Kenner, G. W.; Rimmer, J.; Smith, K. M.; Unsworth, J. F. J. Chem. Soc., Perkin Trans. 1 1978, 845. (c) Smith, K. M.; Bushell, M. J.; Rimmer, J.; Unsworth, J. F. J. Am. Chem. Soc. 1980, 102, 2437.

14. Yoshinaga, T.; Sano, S. J. Biol. Chem. 1980, 255, 4722, 4727.

15. Smith, K. M.; Minnetian, O. M. J. Org. Chem. 1985, 50, 2073.

16. Kenner, G. W.; Rimmer, J.; Smith, K. M.; Unsworth, J. F. J. Chem. Soc., Perkin Trans. 1 1977, 332.

17. Rezzano, I.; Buldain, G.; Frydman, B. J. Org. Chem. 1986, 51, 3968.

18. Games, D. E.; Jackson, A. H.; O'Hanlon, P. J. J. Chem. Soc., Perkin Trans. 1 1976, 2501.

19. Clezy, P. S.; Mirza, A. H.; Prashar, J. K. Aust. J. Chem. 1990, 43, 857.

20. Cavaleiro, J. A. S.; Gonsalves, A. M. d. R.; Kenner, G. W.; Smith, K. M. J. Chem. Soc., Perkin Trans. 1 1974, 1771.

21. Al-Hazimi, H. M. G.; Jackson, A. H.; Knight, D. W.; Lash, T. D. J. Chem. Soc., Perkin Trans. 1 1987, 265.

22. Clezy, P. S.; Fookes, C. J. R.; Prashar, J. K. Aust. J. Chem. 1989, 42, 775. 